\title{
SOCIALPSYCHOLOGICAL STUDIES ON A MASS OF LEPROSY PATIENTS
}

\section{MIKIO MORI}

(National Leprosarium, Oku Komyoen)

It is easily imaginable that the leprosy patients present a peculiar psychological traits, when they are separated spacially and form a semi-permanent social mass.

The group psychology of the patients was examined and compared with the results obtained by Shinichi Ikejiri applying Okabe-Awaji Antroversion-extroversion test.

The results were as following:

1) The introversion or extroversion type of both male and female leprosy patient group situates in the standard range of the Japanese.

2) The mass psychology of leprosy patients tends, though a little (6 in index), outwards.

3) The female patients exhibiting the diseases within 29 years old present more inward propensity than those who have the disease afterwards.

4) 'The male who have been in the leprosarium longer than 21 years become introversive.

5) The male patients staying at home for $1 \sim 2$ years are in more introversion than those who stay longer at home.

The effective treatment of promin, the repletion of the social insurance and the strict regulation against vagrant leprosy patients let them settle down in the leprosarium According to this fact the characteristic change has become remarkable, namely, they become less capricious and take care of their own things. The restablishment of the private property system, such as new built house for married patients, plays a great part for this psycholoicgal change. And also a tendency to settling can be seen in their conciliating attitude without gossipping of others. That the leprosy patients have always sympathy with other informs us of the latent mass preventive words.

The average differences have been calculated with statistical examinations.

\section{ライ患者集団の社会心理学的研究 (1)}

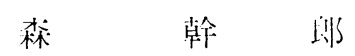

邑久光明園

(昭和 30 年 2 月 28 日受稿)

目次

序: 言

第 1 章 研究対象と研究方洼

調查期日, 調宵対象, 標本抽出法, 调查方法, 記入方 法, 回収率, 標本処理方法

\section{第 2 章 研究成樍}

第 1 条 向性指数に関する成續

向性指数度数分布, 年令別指数, 発病年令別指数, 在 所年数別指数，在宅年数別指数

第 2 条 問題別回答率に関する成績
回答率の多かつた10問, 回答率の少かつた10問, 池少 氏の調查と比較して回答率の殆んど变化していない 問, 池染氏の調查と比較して回答率の著しく変化して いる問, 白紙回答率

第 3 音 総括と考挍

指数の度数分布, 発病留令別に上る差, 在所年数別に よる差，在宅年数別による差，ライ患者集団の性格平 均像

結 言 


\section{序言}

最近精神神経医学といらととがしきりにいわれている が殆んど半永久的に骝離収容せられているライ患者に対 しては一そらそのことがいえよら。元れは彼らがかかる 時間的限定のみならず空閐的限定をも受けているから肉 体的疾病そのものの外便に特有の心理偏向を来してい るでまろうと推祭できるからである。との観点から行つ たライ患者集团の社会心理学研究の一端を報告する。

\section{第 1 章 研究対象と研究方法}

1）調查期日二昭和 29 年 9 月

2) 調查対象二当園入所者 108 名

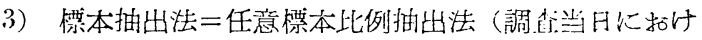
る入所患者を性別，年令別に層化しそれに比例して各 層から無作為に合計数が 100 名に達するように畭本を 抽出した。尚，罗子の 9 才以下，70代，女子の10代， 60 代は愫本数が少いためそれぞれ若干名を加えて各 4
名としたから合計標本数は 108 名となつた。また，年 令は 10 子每に層別した。

4）調圭方法=凮部, 淡路式向性榆查（乙れは昭和18作 に淡路氏によつて改訂やられる以前のもの，即ち昭和 6 年のものである。旧版を用いたのは昭和11年熲故池 凩慎一氏がそれによつて調查されて打り，筆者の意汹 がそれとの比較に重きを㨟いているからである。その 際患者の教育程度がきわめて低いこと艺考慮して若计 用語を平易にした。）

5）記人万法＝自己診断記入法（9于以下の者は他人観 祭記入法によつた。

6) 回收率 $=100 \%$

7）慗本処理方法二推計学的検定を行つた。即ち、トン

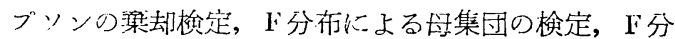
布による有意差の检定である。

\section{第 2 章 研究成績}

筑 1 条 向性指数に関する成䋊

1) 向性指数度数分布

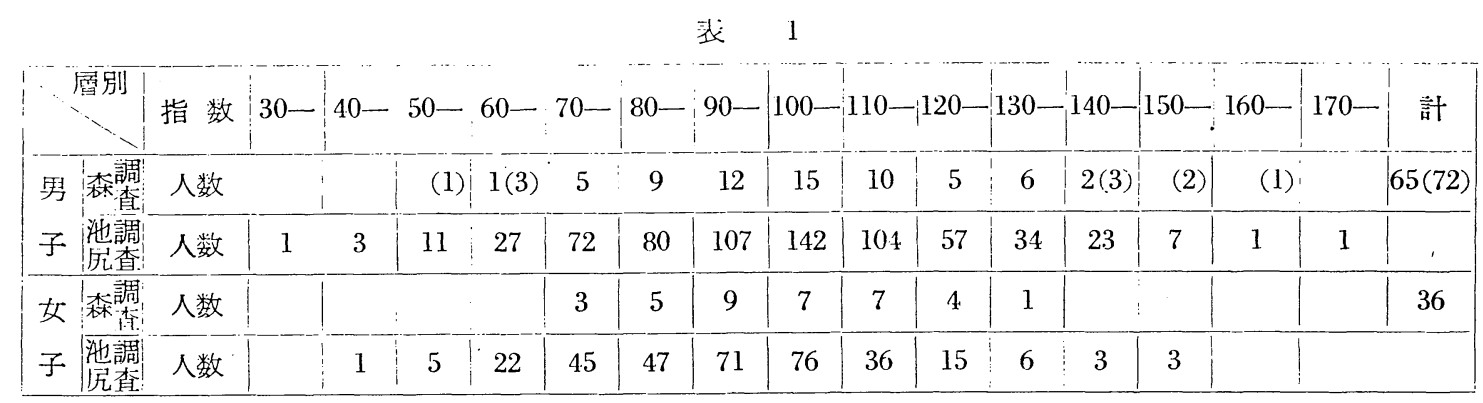

向性指数の算術平均, 標準偏差

\begin{tabular}{|c|c|c|c|c|c|c|}
\hline & & 森 調 查 & & 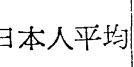 & 再 春 荘 & E森 調 查 \\
\hline 男 & 算術平均 & 106.83 & 84 & 110.3 & 100.2 & 104.81 \\
\hline 子 & 標準偏 & 59 & 64 & .61 & 22.8 & 20 \\
\hline 女 & 術平均 & 0.78 & .38 & 104.8 & \multirow{2}{*}{$\begin{array}{l}\text { 男女の別 } \\
\text { なし }\end{array}$} & \multirow{2}{*}{$\begin{array}{l}\text { 男女を平 } \\
\text { 均して }\end{array}$} \\
\hline 子 & 標準偏差 & 15.07 & 18.76 & 20.37 & & \\
\hline
\end{tabular}

(備考) 人数（榅本数）の中， （）内は寨却前の標本数安示す。 以下゙表も之に同じ。
2) 年令別指数
（表 2)
3）発病年令別指数（表 3 ）
1) 在所年数別指数（袁4)
5）在宅年数別指数（表 5 ） 
表 $\quad 2$

\begin{tabular}{|c|c|c|c|c|c|c|c|c|c|c|}
\hline & 年令 & $0-$ & $10-$ & $20-$ & $30-$ & $40-$ & $50-$ & $60-$ & $70-$ \\
\hline \multirow{2}{*}{ 男 } & \multirow{2}{*}{$\begin{array}{l}\text { 森 } \\
\text { 調 } \\
\text { 查 }\end{array}$} & 人数 & 4 & 4 & 15 & 19 & \multirow{2}{*}{$\begin{array}{c}14 \\
105.29\end{array}$} & 8 & 4 & 4 \\
\hline & & 指数 & 107.00 & 114.50 & 105.73 & 105.20 & & 108.50 & 104.00 & 89.50 \\
\hline \multirow{2}{*}{ 子 } & 染 & 人数 & & 61 & 205 & 186 & 149 & 53 & 11 & 5 \\
\hline & $\begin{array}{l}\text { 調 } \\
\text { 植 }\end{array}$ & 指数 & & 105.40 & 99.06 & 99.31 & 102.34 & 102.34 & 104.18 & 14.8 \\
\hline \multirow{2}{*}{ 女 } & 森 & 人数 & & 4 & 8 & 9 & 7 & 4 & 4 & \\
\hline & $\begin{array}{l}\text { 調 } \\
\text { 售 }\end{array}$ & 指数 & & 102.50 & 100.25 & 92.00 & 102.29 & $(106.50$ & 111.5 & \\
\hline \multirow{2}{*}{ 子 } & 池 & 人数 & & 18 & 84 & 86 & 61 & 51 & 24 & 6 \\
\hline & $\begin{array}{l}\text { 媌 } \\
\text { 查 }\end{array}$ & 指数 & & 90.56 & 93.26 & 92.98 & 97.51 & 93.88 & \multicolumn{2}{|c|}{$98.67: 112.00$} \\
\hline
\end{tabular}

\begin{tabular}{|c|c|c|c|}
\hline 層別 & & $0-79$ & $10-40$ \\
\hline 男 & 人数 & 58 & \\
\hline 子 & 指数 & 107.21 & \\
\hline 女 & 人数 & & 28 \\
子 & 指数 & & 98.43 \\
\hline
\end{tabular}

(備考)

男子平均107.21は，母集団を異に した40代を除いたすのでする。女 子に於ても50代は母集団を異にに ている。

\begin{tabular}{|c|c|c|c|}
\hline 層別 & 年令 & $0-29$ & $30-59$ \\
\hline 男 & 人数 & \multicolumn{2}{|c|}{64} \\
于 & 指数 & \multicolumn{2}{|c|}{102.84} \\
\hline 女 & 人数 & 27 & 5 \\
子 & 指数 & 97.93 & 112.40 \\
\hline
\end{tabular}

\begin{tabular}{|c|c|c|c|c|c|c|c|c|c|c|}
\hline \multicolumn{2}{|c|}{ 層別 } & 年令 & $0-$ & $10-$ & $20-$ & $30-$ & $40-$ & $50-$ & \multirow[t]{2}{*}{$60-$} & \multirow[t]{2}{*}{ 不 } \\
\hline \multirow{2}{*}{ 男。 } & \multirow{2}{*}{$\begin{array}{l}\text { 森 } \\
\text { 調 } \\
\text { 柰 }\end{array}$} & 人数 & $5(6)$ & $24 \cdot(28)$ & $17(20)$ & 13 & 2 & 3 & & \\
\hline & & 指数 & 95.20 & 100.83 & 107.41 & 104.92 & 103.00 & 96.67 & & \\
\hline \multirow{2}{*}{ 子 } & \multirow{2}{*}{$\begin{array}{l}\text { 池 } \\
\text { 成 } \\
\text { 調 } \\
\text { 南 }\end{array}$} & 人数 & 25 & 299 & 244 & 68 & 19 & 10 & 5 & \\
\hline & & 指数 & 93.84 & 98.49 & 102.24 & 106.12 & 106.11 & 100.80 & 106.00 & \\
\hline \multirow{2}{*}{ 文 } & \multirow{2}{*}{$\begin{array}{l}\text { 森 } \\
\text { 調 } \\
\text { 查 }\end{array}$} & 人数 & 3 & 19 & 5 & 2 & 2 & 1 & & 4 \\
\hline & & 指数 & 97.33 & 100.63 & 88.00 & 115.00 & 111.00 & 110.00 & & \\
\hline \multirow{2}{*}{ 子 } & \multirow{2}{*}{$\begin{array}{l}\text { 池 } \\
\text { 忩 } \\
\text { 調 } \\
\text { 梖 }\end{array}$} & 人数 & 17 & 129 & 111 & 39 & 18 & 14 & 2 & \\
\hline & & 指数 & 89.65 & 92.88 & 94.92 & 96.36 & 105.78 & 95.14 & 100.00 & \\
\hline
\end{tabular}

表 4

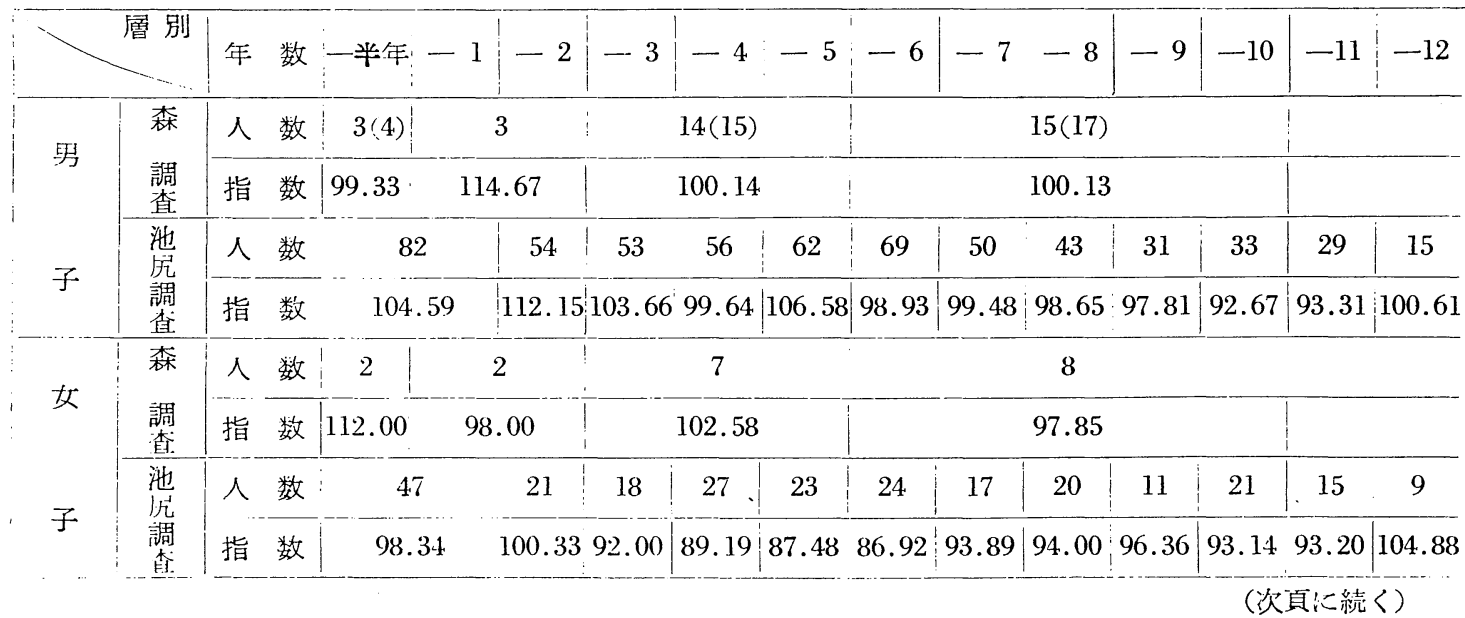




\begin{tabular}{|c|c|c|c|c|c|c|c|c|c|c|c|}
\hline-13 & --14 & -15 & -16 & -17 & -18 & -19 & -20 & $21-$ & $31-$ & $41-$ & 不明 \\
\hline \multicolumn{8}{|c|}{$22(25)$} & 3 & 2 & 2 & 1 \\
\hline \multicolumn{8}{|c|}{106.82} & 90.00 & 88.00 & \multicolumn{2}{|l|}{92.00} \\
\hline 18 & 10 & 9 & 5 & 14 & 10 & 3 & 24 & 1 & 1 & 1 & 1 \\
\hline 99.44 & 92.40 & 94.89 & 98.40 & 100.7 & 94.80 & 90.66 & 94.17 & & & & \\
\hline \multicolumn{8}{|c|}{13} & 1 & 1 & & 2 \\
\hline \multicolumn{8}{|c|}{97.08} & 90.00 & 120.00 & & \\
\hline 5 & 5 & 8 & 7 & 5 & 8 & 4 & 35 & & & & \\
\hline 130.20 & 98.80 & 96.50 & \multicolumn{7}{|c|}{$93.71 \mid 100.80103 .00102 .0095 .77$} & & \\
\hline
\end{tabular}

\begin{tabular}{|c|c|c|c|}
\hline 層 別 & 年数 & -20 & $21-$ \\
\hline 男 & 人数 & 57 & 7 \\
\hline 子 & 指数 & 104.91 & 90.00 \\
\hline 女 & 人数 & 32 & \\
子 & 指数 & 99.38 &
\end{tabular}

歨 5

\begin{tabular}{|c|c|c|c|c|c|c|c|c|c|c|c|c|c|c|}
\hline \multicolumn{2}{|c|}{ 層別 } & 年 数 & 0 & -1 & -2 & -3 & -4 & -5 & $-10 !$ & -15 & -20 & -30 & $31-$ & 不明 \\
\hline \multirow{2}{*}{ 男 } & & 人 数 & $|13(14)|$ & 5 & $\mid 12(16)$ & \multicolumn{3}{|c|}{$15(18)$} & 5 & \multicolumn{2}{|c|}{8} & 2 & 3 & 1 \\
\hline & $\begin{array}{l}\text { 調 } \\
\text { 查. } \\
\text { 戛 }\end{array}$ & 指 数 & 97.23 & 90.40 & 99.17 & \multicolumn{3}{|c|}{106.27} & 104.00 & \multicolumn{2}{|c|}{116.78} & \multicolumn{3}{|c|}{108.00101 .33} \\
\hline \multirow{2}{*}{ 子 } & 池 & 人 数 & & 158 & 57 & 64 & 41 & 4.9 & 154 & 72 & 24 & \multicolumn{2}{|c|}{24} & \\
\hline & $\begin{array}{l}\text { 調 } \\
\text { 查 }\end{array}$ & 指 数 & & 121.11 & $|98.42|$ & \multicolumn{3}{|c|}{$100.00^{1} 103.76$} & 100.38 & 98.25 & 107.33 & \multicolumn{2}{|c|}{101.92} & \\
\hline \multirow{4}{*}{ 女 } & 森 & 人 数 & 2 & 3 & 5 & \multicolumn{3}{|c|}{10} & 5 & \multicolumn{2}{|c|}{$4 \cdot(5)$} & 3 & 2 & 2 \\
\hline & $\begin{array}{l}\text { 調 } \\
\text { 督. }\end{array}$ & 指 数 & 108.00 & 118.00 & 94.80 & \multicolumn{3}{|c|}{98.20} & 99.20 & \multicolumn{2}{|c|}{90.50} & \multicolumn{3}{|c|}{105.33106 .00} \\
\hline & 染 & 人 数 & & 64 & 29 & 22 & 28 & 25 & 80 & 43 & 24 & \multicolumn{3}{|c|}{15} \\
\hline & $\begin{array}{l}\text { 調 } \\
\text { 查 }\end{array}$ & 指 数 & & 98.59 & 92.62 & 92.73 & 95.64 & 93.52 & 94.78 & 93.53 & 90.50 & \multicolumn{2}{|c|}{98.13} & \\
\hline
\end{tabular}

\begin{tabular}{|c|cc|c|c|c|}
\hline 層別 & 年 & 数 & -2 & $3-20$ & $21-$ \\
\hline $\begin{array}{c}\text { 男 } \\
\text { 子 }\end{array}$ & 人 & 数 & 17 & 28 & \\
\hline $\begin{array}{c}\text { 女 } \\
\text { 子 }\end{array}$ & 人 & 96.59 & 108.86 & \\
子 & 指 & & & 33 & \\
\hline
\end{tabular}

\section{(備考)}

在宅年数 0 年といらのは, 発病直後に入所した 者であり，母集団を異にしている。 
算2策 問題別同答率に関する成綪

表 6 問題 別回答百分率

\begin{tabular}{|c|c|c|c|c|c|}
\hline $\begin{array}{l}\text { 番 } \\
\text { 具 }\end{array}$ & 稿 & は男 & $\begin{array}{c}\text { 子 } \\
\text { W }\end{array}$ & 好い & $\begin{array}{c}\text { 子 } \\
\text { w实 }\end{array}$ \\
\hline 一寸したととです気にやみますか & ] & 54. (54) & $42(36)$ & $69(61)$ & $31(32)$ \\
\hline すぐに決心ができすすか & 2 & $46(32)$ & $46(54)$ & $28(22)$ & $64(69)$ \\
\hline 大事をとつて慎重にしますか & 3 & $67(54)$ & $19(24)$ & $58(55)$ & $25(23)$ \\
\hline 決心をかえるととができすすか & 4 & $49(44)$ & $36(33)$ & $42(44)$ & $36(32)$ \\
\hline 考える上り活動する方か㳔きですか & 5 & $67(65)$ & $26(18)$ & $81(61)$ & $11(22)$ \\
\hline 陰気ですか & 6 & $29(30)$ & $60(49)$ & 14. (35) & $81(50)$ \\
\hline 失敗にこりますか & 7 & $58(38)$ & $38(33)$ & $67(55)$ & $25(32)$ \\
\hline のんきですか & 8 & $57(54)$ & $39(34)$ & $56(57)$ & $39(37)$ \\
\hline 無口ですか & 9 & $46(44)$ & $50(42)$ & $31(37)$ & $58(55)$ \\
\hline 感情を顔に出しますか & 10 & $58(53)$ & $35(31)$ & $47(64)$ & $44(28)$ \\
\hline よくはしやぎすすか & 11 & $42(45)$ & $42(39)$ & $39(52)$ & $53(37)$ \\
\hline うつり気ですか & 12 & $22(42)$ & $57(40)$ & $17(42)$ & 64. (38) \\
\hline こり性ですか & 13 & $51(45)$ & $38(36)$ & $53(41)$ & $42(37)$ \\
\hline しルぼら強いですか & 14 & $58(45)$ & $38(37)$ & $67(46)$ & $28(38)$ \\
\hline 理くつぽいですか & 15 & $32(38)$ & $58(46)$ & $33(39)$ & $56(40)$ \\
\hline 議論が過激になり易いですか & 16 & $32(24)$ & $53(47)$ & $19(24)$ & $56(40)$ \\
\hline 用心深いですか & 17 & $72(51)$ & $25(35)$ & $58(60)$ & $28(31)$ \\
\hline 動作がきびきびしていますか & 18 & $36(37)$ & $49(43)$ & 44. (38) & $42(29)$ \\
\hline 仕事が綿密ですか & 19 & 44. $(40)$ & $43(41)$ & $56(35)$ & $25(44)$ \\
\hline 派㐿な仕事が好きですか & 20 & $40(42)$ & $49(38)$ & $31(26)$ & $53(55)$ \\
\hline 仕中に营中になりますか & 21 & $71(53)$ & $21(30)$ & $78(55)$ & $22(32)$ \\
\hline 空梖家ですか & 22 & $40(40)$ & $43(40)$ & $44(43)$ & $47(42)$ \\
\hline 潔薜家ですか & 23 & $57(24)$ & $26(42)$ & $42(28)$ & $28(35)$ \\
\hline 持物を粗雑にしすすか & 24 & $22(33)$ & $67(53)$ & $14(28)$ & $81(58)$ \\
\hline 無䭾づかいが多いですか & 25 & $40(41)$ & $56(45)$ & $28(32)$ & $64(59)$ \\
\hline 話し好きですか & 26 & 54. (51) & $38(38)$ & $53(52)$ & $39(38)$ \\
\hline 気むずかしいですか & 27 & $31(34)$ & $58(4.7)$ & $25(31)$ & $61(47)$ \\
\hline 笕談在言いすすか & 28 & $67(68)$ & $26(24)$ & $81(62)$ & $14(30)$ \\
\hline 打だてられ易いですか & 29 & $31(31)$ & $58(48)$ & $11(20)$ & $67(45)$ \\
\hline 強情ですか & 30 & $51(48)$ & $40(35)$ & $47(55)$ & $33(29)$ \\
\hline いつも不滥が多いですか & 31 & 24. (38) & $61(44)$ & $39(43)$ & 14. $(42)$ \\
\hline 自分のウワサが気になり屯すか & 32 & $60(25)$ & $36(47)$ & $53(68)$ & $36(24)$ \\
\hline 他人のウワサがしたいですか & 33 & $19(26)$ & $69(53)$ & $8(26)$ & $78(44)$ \\
\hline 目分のととを他人に委せられすすか & 34 & $36(30)$ & $56(4.9)$ & $31(29)$ & $58(55)$ \\
\hline 人から指汹されるのがいやですか & 35 & 54. (48) & $32(33)$ & $69(64)$ & $17(35)$ \\
\hline 人の」にに立つてらまく治められますか & 36 & 24. (13) & $58(56)$ & $8(21)$ & $47(49)$ \\
\hline 他人の意見を素直に聞きいれられますか & 37 & $67(47)$ & 14. (32) & $4.7(44)$ & $33(30)$ \\
\hline 気がききますか & 38 & $35(24)$ & $43(49)$ & $42(23)$ & $47(62)$ \\
\hline かくし立てをしますか & 39 & $20(26)$ & $61(52)$ & $17(31)$ & $67(50)$ \\
\hline 他人にすぐ同情しますか & 40 & $76(60)$ & $10(22)$ & $75(65)$ & 11 (24) \\
\hline 他人を信じすぎすすか & 4.1 & 44. $(40)$ & $43(38)$ & $56(35)$ & $31(42)$ \\
\hline ウラミが忘れられないですか & 42 & $51(43)$ & $38(37)$ & $64(44)$ & $28(32)$ \\
\hline はにかみ屋ですか & 43 & $36(24)$ & $47(44)$ & $36(38)$ & $53(40)$ \\
\hline 独りでいるのか好きですか & 44 & $28(37)$ & $57(49)$ & $47(42)$ & 44. (45) \\
\hline 友人は仲々できませんか & 45 & $31(37)$ & $63(44)$ & $28(38)$ & $61(35)$ \\
\hline 人前で平気で話せますか & 46 & $46(34)$ & $50(51)$ & $33(24)$ & $47(54)$ \\
\hline 人前でいりも引つこんでいますか & 47 & $36(45)$ & $53(33)$ & $25(43)$ & $50(29)$ \\
\hline 意見のちがら人とも気軽につきまえますか & 48 & 44. (38) & $42(42)$ & $42(35)$ & 44. (44) \\
\hline 世話好きですか & 4.9 & $53(36)$ & $31(39)$ & $53(32)$ & $36(46)$ \\
\hline 人に物を情しまずにキりますか & 50 & $63(36)$ & 24. (38) & $58(34)$ & $28(37)$ \\
\hline
\end{tabular}

○数字は「はい」㕛は「いいえ」と答えた者を百分比で表わしたものでせる

○「はいよ「いいえ」の合計数と 100 との差は無回答, むしくは重答でもる

○（）内の数字は池底氏の調尛によるものでもる 
1) 问答率り多かつた：日問

男 $=63$ \%以上: $(3,5,17,21.24,28,33,37,40,4$ $5,50)$

女 $=67 \%$ 以上 $(1,5,6,7,14,21,24,28,29,33$ ，

$35,39,40)$

2) 回答率の少かつた10問

男 $=24$ 。以下 $(3.12,21,24,31,33,36,37,39,4$ $0,50)$

女 $=17$ \%以下 $(5,6,12,24,28,29,33,35,36,3$ $9,40)$

（註）1）2）に拈ける男女共通の回答は第24問，分33 問，第40問で\&る。

3）池尼氏の調查と比較して回答率の殆んど変化してい、 ない問（「はい」「いえ」の増減の合計が5\%占以ト） 男 $=22,26,28$ 女立 $=3,8,17,26,34$

4) 池尼氏の調查と比較して回答率の著しく变化してい る問（「はい」「いい」の増減の合計が20\%以け） 男 $=12 ， 17 ， 23 ， 32 ， 50$ 女 $=6,12,19,24,33,41,47$

（註） 3）及び 4）に扣ける男女共通の回答はそれぞれ， 第26問及び第12問で岕る。

5）白紙回答率

\begin{tabular}{|c|c|c|c|c|c|c|}
\hline \multicolumn{3}{|c|}{ 筆者 } & \multicolumn{4}{|c|}{ 池氿氏 } \\
\hline 馜 & \multicolumn{2}{|c|}{$11.3 \circ$} & \multicolumn{4}{|c|}{ 19.9 } \\
\hline 㰠 & \multicolumn{2}{|c|}{$13.2 \%$} & \multicolumn{4}{|c|}{$18.4 \%$} \\
\hline 平均 & \multicolumn{2}{|c|}{$12.2 \%$} & \multicolumn{4}{|c|}{$19.1 \%$} \\
\hline \multirow{3}{*}{\multicolumn{2}{|c|}{ 白紙率 (\%) }} & & 問 & 題 & \multicolumn{2}{|c|}{ 数 } \\
\hline & & \multicolumn{3}{|c|}{ 男 } & \multirow{2}{*}{\multicolumn{2}{|c|}{$\begin{array}{c}\text { 女 } \\
\text { 筆者池婜氏 }\end{array}$}} \\
\hline & & 筆 & 者 & 池尻氏 & & \\
\hline $0 \sim$ & 5 & & 9 & 0 & 9 & 1 \\
\hline $6 \sim$ & & & 10 & 2 & 9 & 10 \\
\hline $11 \sim$ & & & 21 & 9 & 17 & 10 \\
\hline $16 \sim$ & 20 & & 8 & 20 & 9 & 7 \\
\hline $21 \sim$ & & & 2 & 19 & 6 & 22 \\
\hline
\end{tabular}

白紙率 $21 \%$ 以.:の回答

男 $=12,38$

女 $=4,16,23,29,36,47$

池的氏の時も筆者の時も白紙率10?以下の回答

男 $=1,28$

女 $=1,2,8,10,25,26,28$
（部）是女共涌の)回答は第！問，第28問

\section{第 3 章 総括と考按}

前章第 1 条については推計学的に有意の善の認女られ たものについてのみ考祭してみる。

1) 指数の度数分布

筆者の成績と池尻氏のそれとを比較すると，男女とも それぞれ指数に扣いて約 6 増加している。池肩氏の調 查の素材を知り得ないので推計学的有意差を検定すると とはできないが，算術平均だけを比較すると，乙の20年 間にライ患者集団は僅かではむるが男女共に外向化して いるととを知る。とれは療養所の経済面の向上, プロミ ンによる治療成果等に基くものであろら。ライ患者集団 の平均を日本人の平均と比較すると, 少しく内向的では あるが男女共に日本人の標隼域にある。しかし20年前に は殆んど標凖域になかつたので步るから，今日のライ患 者集団は巷間想われている任どには内向的でないととを 知る。

池㕂氏は超内向域にむる21例（指数 56 以下）を「とれ だけの指数低下の原因は疑らまでもなく当然その後天的 に背負いてまされた業病に求めらるべきである」と断定

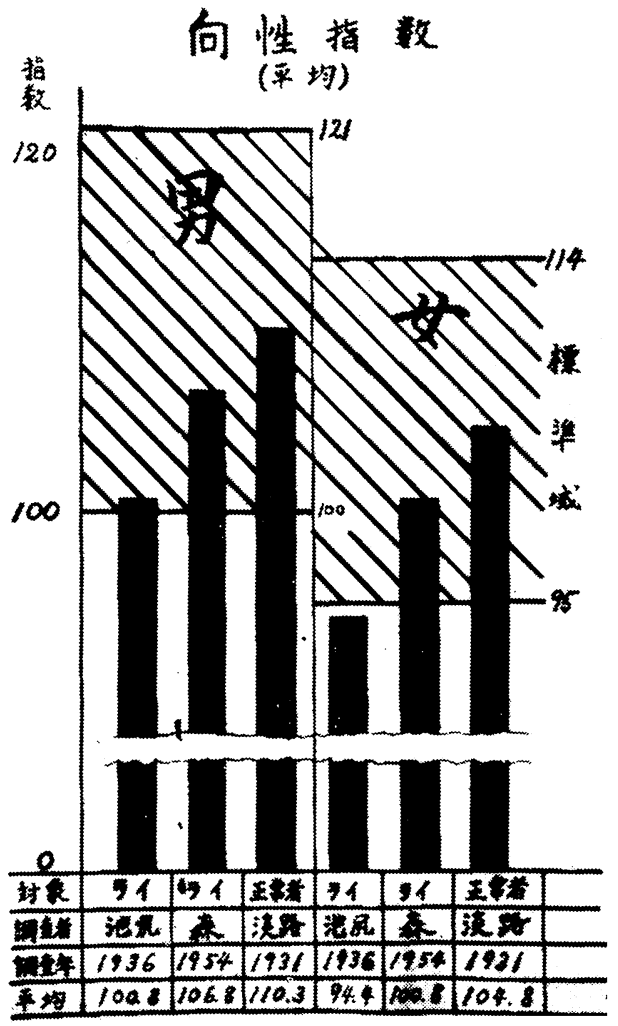




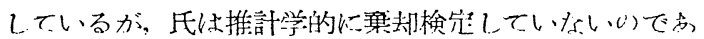
るからこの断定は早計である。な扔, 筆者の調南に打い て裹却した標本の指数は，56，64，66，148，150，156， 162 である。

指数は正規分布曲線を成してかなり広沉に分布してい る。九州再春荘に招ける肺結核患者85名と比較すると, 推計学的検定はできないがライ患者の方が僅かに外向的 である。

2）発病年令別による差

女子に於ては29于までに発病した者の方が，それ以後 に発病した者より内向的である。乙れは年令が若い、蛙ど ライ発病によるショックが大きくしか文子小方がその 影響の著しいととを意味するもので主る。このととは池

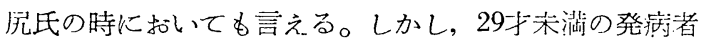
でも今日に颃いては日本人の慗凖域内には学る。

$$
\text { (登病算令考) }
$$

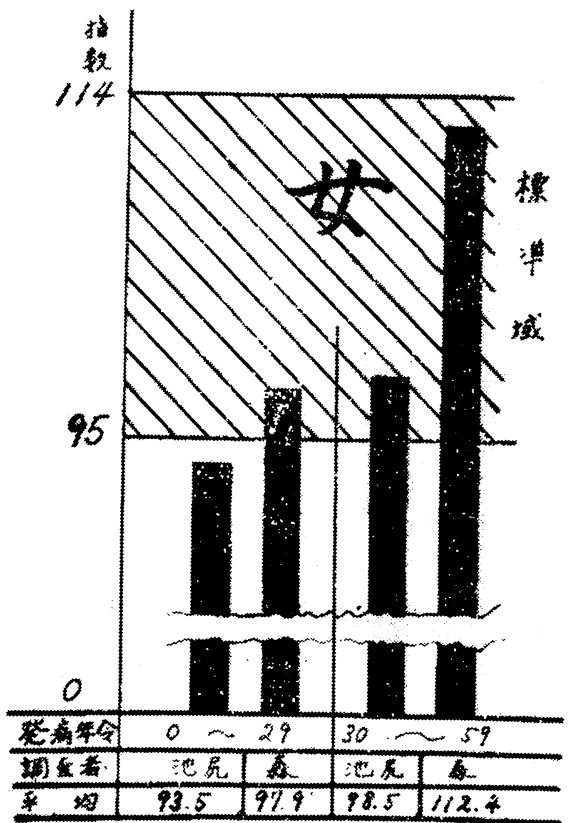

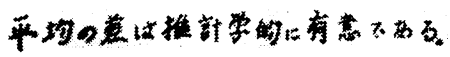

3）在所年数別による差

罗子に扣いては在所年数21年以1:の者はそれ头滥の者 よりも队向的でめる。このことは池沙氏の梅本について もいえる。その理由は入所して20年も経てば多くは故里

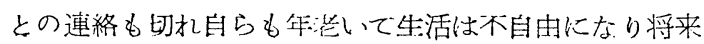

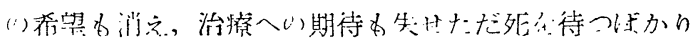

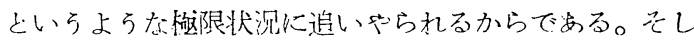
て年老いれば艺いる㭱ど男の方が文よりも重るからこの 心理的な变化は男子に一无ら著しいので方る。な扣，21

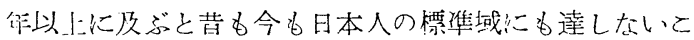
とに留堭す心゙きでせる。

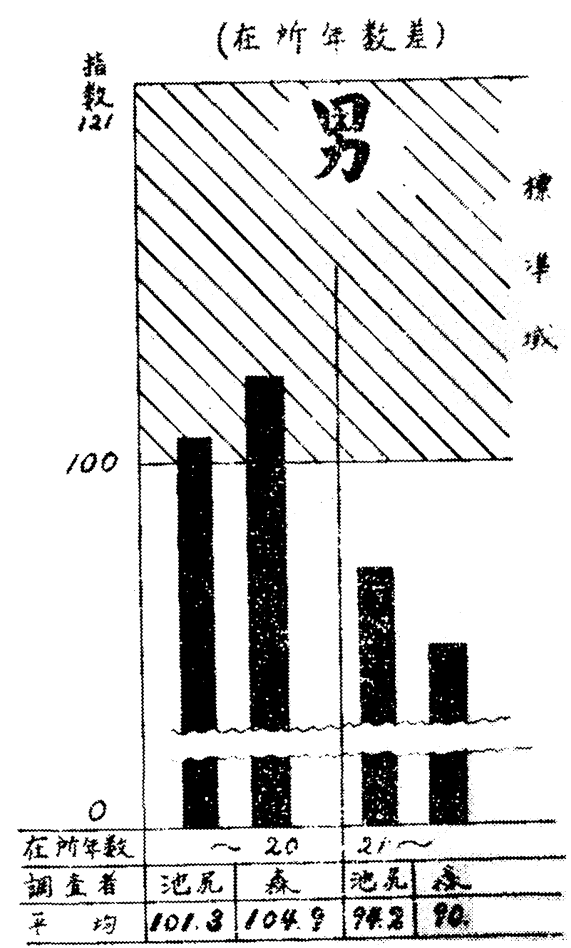

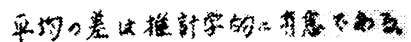

4) 在宅酸别行よる差

男子に括いては在宅 1 ～ 2 年の省がそれ以上の者より も内向畃でもり，日本人の䊈凖域以下でする。こ机はこ の蒯間がライゆえの迫害が一笛莧しい時で，てれにいた 子つけられたものと思ら。逆にい之代，病状加元与重く

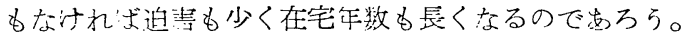
池泥氏の 1 ～年がきわめて高い指数を見せているが， 衰却检定しでいないので間題にし得ない。

5）ライ患者集団の性格平均像

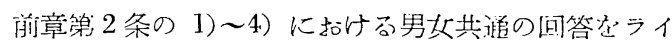
靑者集団の向性椧查加ら与之られた性格平均像と見て上 小ろら。以卜，この回管老中心にライ患者生活史にふれ つつこれ花梦穴てみたい。

私行的特徽 


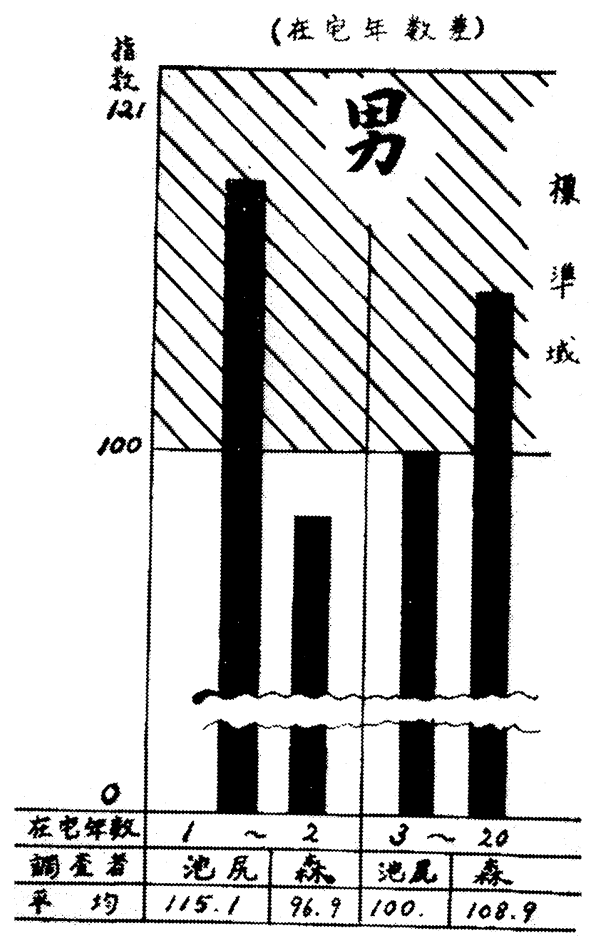

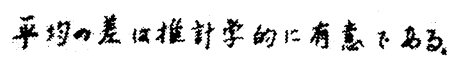

移り気でない

持物を粗雑にしない

社会的特徵

話し好きでする

他人のウワサはしたくない

他人にすく同情する

敗戦が幸いしたといらと変ないい方になるが，敗戦の 結果改善向上せられた面は大は国家のととから小はわれ われの身辺のととに到るをで数少くない。社会保障制度 の充実といらとともその一つである。しかし勿論未だし の点は多々言るので国家㐨算の中厚生省㐨算は $6.42 \%$ （昭和 20 年〜29年平均）ほどである。けれども旧来の日 本のととを想えばとにかく一心は軌道に乗つて来たとい えよう。中でもライ予算は優遇されているのではないだ そうか？

昭和 27 年度 $1,430,441,000$ 円

昭和 28 年度 $1,671,947,000$ 円

昭和 29 年度 $1,749,008,000$ 円

また 1 人 1 日当の支出額を見ても 335 円 13 銭 $(28$ 年度 11国立療養所战出決算の平均）となつている。今日の日

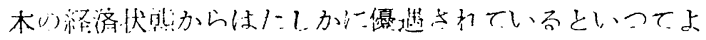
い。

往時のライ療養所がその経済面から見ていか低位の 为のでぬつたかは筆者如き若辈の詳言を要せ奴ところで 出る。従つて昔は自発的に入所して来る患者なども殆ん ぞなく，一方，悲には乞食浮淇する患者の姿は跡を絶た なかつたといれれる。それ故, 政府のライ対策もとれら の浮浪气食ライを㵝離収容することが第一であつた。

しかし，これらの強制収容せられて来た患者，まるい は家庭から半ば強いられて連行された患者の中には, 療 養所での生活に耐兊か和，心るいは古里の山河に望郷の 念いを弲られ，また，もつといろいろ複雑な家庭的な問 題の解決を迫られて脱走する者も少くなかつた。勿論そ のまま家庭に戻る者もいたが，浮浪中を収容された者は 殆んどもとの古巣に帰つていつた。そとには運よく狩り こみの追手を逃れた患者たちが，集団の威をかりで，つ よくたくまして生きていたのである。とてに行けば，た だライ患者であるというだけの理由で住所氏名は明さな いでも代護されたのである。

その団結力が異常なまでに強いととはいわゆる部落民 のそれに似ている。と机は両者共「不浄」なモノとして 異質視されて来たからでめる。一方は身分, 他方は病気 を秘女て生きねばならないといら共间の関心の上に結ば れているが，彼らは集団として内的に団結するととによ つて防衛効果の上ることを体験的に知つていたのでも る。しかし近年ライ療養所の施設, 待遇も徐々に改めら れ，且つ，プロミンの治療效果も上つて来たととが, 患 者の性格, 行動, 生活を一变したととはいらまですな い。その中のもつともなるものはライ患者の療養所への 「定着化」という現象である。乙れを逆に脱走者の減少 といら事実から見てみよら。即ち当園の開設（明治 42 年）以来今日をでの 45 年間を昭和 6 年を境として二分す ると, 後半の脱走者 (461 人) は前半 (1600人) のそれ の四分の一ほどである。昭和 5 年に䨓生園， 7 年に楽泉 園, 10 年に敬愛園がそれぞれ創立されているから, 昭和 初年頃からいよいよ政府もライ対策に力を注き始めたと いらととができよう。即ち浮浪ライ取蟐りの強化といら こともその理由として考えられるが，昭和も中頃に入る と段々定着化の傾向を見せ出して来たととは事実でむ る。最近は脱走者も殆んどない。たまにあつても三角関 係を清算するため他園に馳落ちするぐらいのものである ら。20年前に比へて, 移り気でない, と答える者がふえ ているのもその一つの表われであろら。浮浪の生活を送 つていれば, 打のずから，性格の移り気になるのも止む 


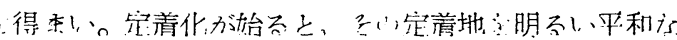
ところにしたいと影らのは人情で出る。例えば，持物芒 大划にするなどといらのもその一つの表われではないだ ろらか?

といらのは物を粗末にすれば直ちに困るのは本人だか らでむる。それは幾ら生活を保証されていてもそらで岁 ろら。作しとの持物を大切にするといら傾向が著しく表 われて来たのは戦後夫婦舎か澵築されるよらになつてか らのととで齿る。夫婦舎の新築の結果ライ療養所内には 始めて私有財産制度か滩立せられたからでめる。それ以 前には15畳とか30畳とかの共阔生活で女つたから，そこ では凡て共有であつた，と云えよう。

私有財産ができたから持物を大切にするようになつた といらことは，逆に云えば，共有時代，又令日でも公有 物は相末にするといらことで岕り，之は文我々の钼祭と 全く一致している。我々の間では過剩給与説さ六真面目 に論議される任どで䊦る。

洸者は訝るか子しれない。初しい，物のない時こそ人 は物を大甽にする等ではないか？と。併しことにライ 患者の悲哀が女,つたのでむる。昔は病状多不安定でいつ 死妨か分らない上らな重症の患者が多く，生活は暗く みじめだつた。その人生はその日その日の連続にしかす ぎず，過去は出つても来来佉なく，現在を支配するすの 㤥観に根ざした刹那主義でしかなかつた。このよらな 生活から，未来に連る建設的な生活設計が生孔て来るだ ろらか？ 公の物は勿論目分のものさえも大事にしよう などとは考えないのではないだろらか！

定着化に伴つて精神的な努力も行われるようになつ た。つ京できるだけ気柰ずい空気をつくる末いとの願 でむる。それは，他人のウワサはしたくない，といら願 いにも表れている。

そもそもウワサと云らものは実に瀑力を振うもので志 る。先ず全然当人の知ら如閆に弘まるととが多い。そし て弘まり易いよらに，簡単に一部分が省かれてしまう。 その省略化の過程で一そう真実性から遠ざかることにな る。そして針小柱大に迄も膨脹しつつ拡散していく。ウ ワサは叉伝聞，風説，Hearsay とも言われるととで明 らかなよらに，伝え聞いたます又話され，その真偽の確 かめられることなど殆んどない。文，風の如く疾く来り， 疾く去るから訂正のいと末すない。とうして反プクされ つつ真実らしくなつていく。もしそこで反証を挙げて弁 解しようとしても結局は，却つてそのウワサの真実性を 高めるととになるだけである。

こうしてウワサは無聑に苦しタ退屈をかてつライ患者

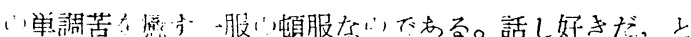

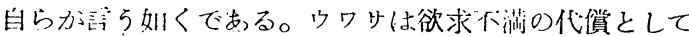
生れることが多い。ウワサを楽しむ流布者たちは当人の 欠点短所を攻撃するばかりではなく，当人がそのウワサ を知らない時にはその間抆けさ加減をも朝笑して快感を 得，運㤠く自分を訪れなかつた優位性をねたみ、そねむの である。つまり欲求不充足者に自慰作用を与えるもので むる。話し好きだ，と言らのも語るに落ちるとはこのと とで，ウワサはしたくない，とは言いながら話の内容の 多くはウワサでめろら。今も昔も男も女も話し好きなこ とには変りないようで女る。併し池层氏の言うように之 を生活の単調とか無例の+いにするのは皮相的観察では。 ないたうらか?

働くと云つても4前中 $2 \sim 3$ 時間軽作㘹をするのガ精 一林でせる彼らが，その外の時間を何一つするとともな くポッンと坐つていたら一体どらなるでせろら？ 恐ら く何の罪めなくしてライ菌に犯されるととになつた我と 我が身を呪い，余りにも苦しい境遇，悲慘な不自由な病 状から，むしろ生より名死を欲し，又，残して来た家族 のことを想い，どのよらな米来か待ちかをえているのて 专ろらかと不安焦懆心心の壁をかきむしられない訳には いかないでもろら。このような現実から一睃でも逃澼せ んとて计間話やウワサに時をすごすのでめろら。そこに しか救いのない生活なのではないだろらか？

他人のウワサは単調苦を破る清凉蝺かもしれないが， 併し，自分がウワサの発源地と思われても困る，又，そ の材料にされるのもいやだと考え，又，ウワサはよくな いもので出るとい倫理的な価傾判断から，ウワサはし たくない，と，答えているので步つて，Sein は Sollen の如くではない。

昔20年前には目分のウワサが気になると答えた男は25 。おだつたのに筆者の調㮐では60\%にも及んでいる。之は 㫮なら自分のウワサが気になり煩わしくなれば脱走して も生活には困らなかつたでせろうから，そらウワサにも 気にもならなかつたものが，今はそれもならず定着する よらになつたから，やはり自分のウワサが気になるので あろ5。

社交的動物で岁る人間が孤独で生きられる筈がない。 人の口の端にも上るととなく，広いガランとした30畳の 大部屋の片隅で督漠を友として生きるには的えられな い。だから孤立を恐れて存在が目立つよらにと振舞らの である。自分のウワサをかぎ回り例え悪口であ言われて いれば，自分か涊れられてはいなかつたととを知り安心 するのである。 


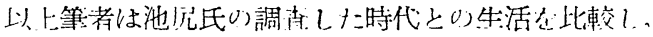

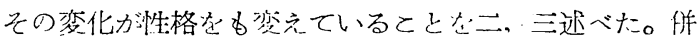
し再回を通じて共に患者の平均像として笔げられてい各 性格が恕る。それは，他人にすぐ同情する，とい美徳で 岁る。

问病㥵橉む。といら言葉も㐫るが，之はライ患者集団 の特色である⿸丆口出のかしれない。近所の人や友人，そして

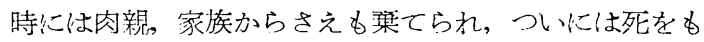
決してやつて来たライ患者を慰め，励まし，相憐及，闰 情の添なこぼして来たのは一体誰で㤁つたろら？フマ ニテに溢れた医師や職員, はた又看護婦加？成程こう で必つたかもしれない。併しそれよりも誰よりも同じラ イの身を生きる㴓者自身でむつたにらがいない。彼らは 世捨人といら共通の宿命の担い手として, 親兄弟よりも 親しく団結し，運命共同体意識の下にかばいあい扶けあ つたのである。こ5した患者集団は社会的别同性の必要 に迫られて生れた家族的集合の延長であつたから，家族 結合の要团である互助相愛はそのまま集団結合の要团と しても愛けつがれたので山る。併しこの信高き慈悲心 をそのま李直ちに高貴なる愛他心と解䭾してもいいもの であろらか？勿論純粋にそうである場合を決して否定 はしないが併しその外面如ボサッ，内面如ヤシャ性を指 摘しない訳にもいかない。

人間は逆境に扔か扎ると順境に导る人々をららやすし がるものでむる。そして順境にある人が逆境に転落する と安心するもので专る。心理的な距離感が短縮せられた ととによつて，自分が逆境から上昇したよらに錯覚する のである。乙こで昰魔は跳梁し始める。即ち，一人でも 仲間に引き入れよう，逆境に引張りこもらとさえするか らでめる。一人仲間がふえることはそれだけその集団の 威力が増加するととだからである。併し心中幾らそらは 思つてぬ口には同情の言葉を忘れない。蛇の如き举さで

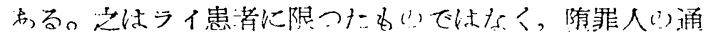
准性でり支ろら。結論总与六るなら，他人にすぐ阔情す る，というその答には多分に恐魔の㓌影が秘女られてい るのでは多ふいか？

白紙率の中，目立つのは「人の上に立つてうまく治め ていけるかどらか分らない」人が45\%ら扣り，之と関連 して，47\%のの人が，らまく治めていけない上答えている ことで出る。女の旧来の地位を物語るものでむろら。

\section{結言}

1) ライ患者集団の向性は男女共日本人の標㔼域に这 る。

2）この 20年間に患者集団の向性は僅かではむるが（指 数に於て 6) 外向化した。

3）29才未満に発病した女子はそれ以後に発病した女子 よりも内向的で出る。

4） 21 年以上在所していると男子は内向化する。

5）在宅 $1 \sim 2$ 年の男子はそれ以上の男子よりあ内向的 である。

6）患者は療養所に定着化の傾向を示して来たため性格 の上に変化が見られるに到つた。即ち20年前よりも移 り気ではなくなり，自分のものを大切にし，他人のウ ワサはしまいと思らよらになつた。

7）患者は 20 年前も今も，他人にすぐ同情する，と答え る者が多いが，之には集団防衛的要素が多分に含まれ ている。

\section{文献}

心理学研究 ( 7 の $1,3,8$ の )

レプラ（7の 115 頁〜，8の 743 頁〜，9の 407 頁〜）

(本稿は八事療養所深津要博士の御指尊に負 万所大さ い。記して感謝する。) 